\title{
Nasionalisme Sumber Daya Manusia Wirausaha dalam Pembangunan Bangsa
}

\author{
Rahmat
}

The problems are intemal and extemal as scope of the Human Being Resources (HR) included.the Human Being - Resources of Entrepreneur (HRE). As HR agent and objective in nation development process. Muhamad (2000:9) said that the human being influence in development to many problems like; planning, value sistem consideration and society. HRE prepare to everyting that become nationl problem. It is not only grow the economic sector but whatever the conceming nation development such as; confidence, skill at organizing, high level of energy, value of achievement over money, that support and keep stability all of nation development sector.

The concerning about it, HRE probably seemb inheren in own self as the fenomena of characteristic HRE. Whereas, the role of HRE is as the important factor and certain in the economic field development. Therefopre, in totality national development all of society elements are needed to support stability such as; materiil, HR and included HRE. How do HRE comprehend the nationalism to or in national development?

To analize this case, begin from the meaning of nationalism, the support factor born ationalism/national identity, right and responsibility of society nationalism, characteristic of nationalism HRE, comprehension of nationalism HRE, implication of Islamic to comprehension of nationalism HRE, strategy of comprehension of nationalism HRE, and perspective view of comprehension of nationalism HRE.

The result of study in this case viz; HRE have the characteristic that seemb to be examined the own personality become the civics that prepare to comprehend the nation identity/nationalism in nation development. The characteristic approach namely, life skill and life social skill. Dedication transformatiom HRE become mental character building.

Kata kunci: nasionalisme, sumber daya manusia wirausaha (SDMW) dan etos kerja

Ometian etiap negara memiliki visi. Visi yang depan depan.Visi negara atau visi pembangunan bangsa. Berarti melihat jauh ke depan pembangunan bangsa termasuk mem- bangun negara Indonesia. Misalnya bervisi membangun bangsa indonesia seutuhnya. Untuk dapat merealisasi dalam visj, maka perlu dilakukan operasional seperti diungkapkan melalui misi. Contohnya; bermisi pembangunan bangsa dalam kesejahteraan material dan spiritual. Selanjutnya, secara operasional perlu memformulasi tujuan yang menjadi arah 
mendasar dalam pembangunan di segala bidang. Salah satu pembangunan adalah bidang ekonomi. Sektor ini merupakan jantung perekonomian secara makro dalam menopang kesejahteraan bangsa.Pertumbuhan ekonomi meningkat dapat dilihat dari fenomena-fenomena maraknya hasil industri dengan produk-produknya. Berbagai jenis produksi menggambarkan betapa merebahnya efektivitas kewirausahaan.Suryana (2003:50) menegaskan bahwa wirausaha berperan sebagai: penggerak, pengendali dan pemacu perekonomian suatu bangsa. Dari peran kewirausahaan itu dapat dipahami usaha untuk menambah nilai dan bertumpu pada sikap manusia selaku usahawan sebagai Sunber Daya Manusia Wirausaha (SDMW) dalam aktivitas kewirausahaan memegangi kepribadian bangsanya.Kepribadian bangsa secara filosofi tertuang dalam dasar negara dan filosofi bangsa. Secara terbuka setiap manusia apapun profesi dengan latar belakang masing-masing termasuk pemberdayaan Sumber Daya Manusia berwirausaha harus mampu menciptakan perannya sebagai warga negara. Untuk itu, proses dinamis wirausaha harus memberikan andil baik langsung maupun tidak langsung kepada proses pertumbuhan ekonomi.Manusia merupakan agen dan tujuan dalam dalam proses pembangunan paripurna suatu bangsa. Ini berarti Sumber Daya Manusia (SDM) sebagai bagian yang diterminan lagi esensial dalam pembangunan bangsa. Hal ini Muhammad (2000:9) menyatakan bahwa manusia adalah penggerak dalam pembangunan yang mengantisipasi berbagai masalah, membuat perencanaan, mempertimbangkan sistem nilai agama dan masyarakat. Menggali sumber alam, mengakumulasi dana, membangun hubungan organisasi sosial, ekonomi dan politik dan meletakkan semuanya dalam satu wadah "pembangunan".Berbagai problematika bangsa seperti; merajalela perilaku korupsi bagaikan jamur di musim hujan, persekongkolan yang dilakukan oleh kaum terpelajar yang sulit dideteksi pelakunya dalam suatu birokrasi dan lembaga tertentu berujungnya juga pada suatu jabatan dan manipulasi finansial, berbagai usaha yang dimonopoli, terjadinya transaksi finansial di luar prosedur dengan oknum perbankan, pemindahan finansial dari dalam negeri ke luar negeri, masih rendahnya pertumbuhan ekonomi bangsa, sempitnya peluang pekerjaan, politik luar negeri terkesan terjadi krisis diplomasi, perhatian manajerial terhadap Sumber DayaAlam (SDA) bemilai ekonomis strategi yang dimanfaatkan oleh negara lain yakni pulau Sipadan dan Langitan lepas dari wilayah RI tahun 2001, ketegangan daerah perbatasan berkenaan blok Ambalat dan Ambalat timur potensial sumber daya ekonomi termasuk rendahnya mutu pendidikan bangsa. Persoalan itu dapat dikatakan menjadi dua hal yaitu persoalan dalam negeri (internal) dan persoalan berkaitan dengan negara lain (eksternal). Masalah Internal dapat dikategorikan manajerial dalam interaksi Poleksosbudhankam sedangkan persoalan eksternal dalam kategori lintas Negara tetapi dapat disebut cakupan jaringan (networking). Problem internal dan ekstemal merupakan kawasan setiap SDM termasuk SDMW bahkan sebagai lawan melainkan seperti tantangan tetapi sebagai kawan. SDMW siap menghadapi apapun termasuk jika memang itu disebut dalam kelompok problema bangsa. Tidak hanya sektor pertumbuhan ekonomi segi apa saja berkenaan dengan pembangunan bangsa SDMW percaya diri, berdedikasi sebagai fighter menegakkan dan mendorong serta menjaga stabilitas semua sektor pembangunan bangsa. Demikian 
halnya dengan dibangun jaringan memiliki komitmen strategis saling memberi perhatian terhadap kepentingan kedua belah pihak . Dari berbagai problema bangsa tersebut mungkin dapat dihindari dengan adanya fenomena pada SDM pelaku manajerial yang mungkin berkarakteristik; produktif dimanifestasikan dalam sikap, nilai dan tingkah laku dalam kehidupan sosial. Ciricirinya meliputi keterbukaan terhadap pengalaman baru, membaca perubahan sosial, realistis terhadap fakta dan pendapat, orientasi kini dan mendatang bukan pada masa lalu, berencana, percaya diri, aspiratif, berpendidikan dan berkeahlian, respek, hati-hati, memahami produksi dan inovatif, berkemampuan menejerial dan siap menghadapi tantangan berbagai aspek kehidupan berbangsa. Gejala dengan karakteristik itu merupakan fenomena jati diri bela negara selaku warga negara. Berkenaan dengan itu, SDMW dimungkinkan inheren dalam dirinya fenomena karakteristiktersebut.Oleh karena itu, kiprah sumber daya nanusia wirausaha harus sejajar dengan berbagai aspek pembangunan bangsa. Problematika bangsa bukan menjadi perhatian pemerintah, tentara, polisi, pegawai negeri dan lainnya tetapi termasuk manusia wirausaha dan seluruh unsur masyarakat dengan latar belakang masing-masing.Tampaknya berbagai persoalan bangsa itu berlarut-larut penyelesaiannya dimungkinkan masih lemahnya menemukan solusi untuk menghentikannya adanya keterlibatan berbagai pihak baik swasta/usahawan maupun dari oknum pemerintahan. Selama ini seolah-olah SDMW melakukan aktivitas kewirausahaannya untuk memperoleh profit (profit oriented). Padahal peranan wirausaha merupakan faktor yang penting dan cukup menentukan dalam pembangunan ekonomi. Untuk mencermati keberadaan SDMW memiliki (handarbeni), merasakan (ngrungkepi), berani mati (toh nyawa) terhadap ibu pertiwi (negeri) perlu terlibat tidak hanya pada sektor tertentu saja melainkan juga secara menyeluruh jiwa raga bagi bangsa untuk bela Negara terhadap berbagai masalah bangsa.Dalam pembangunan bangsa seutuhnya terkait semua unsur masyarakat diperlukan untuk mendukung stabilitas material, SDM, termasuk SDMW. Untuk itu perlu dikaji mengenai bagaimana pemahaman nasionalisme SDMW terhadap/dalam pembangunan bangsa/perspektif pembangunan bangsa.

Dalam tulisan ini fokus permasalahan yang diutarakan adalah bagaimana pemahaman nasionalisme Sumber Daya Manusia Wirausaha terhadap/dalam pembangunan bangsa/perspektif pembangunan bangsa?

\section{Pengertian Nasionalisme}

Menurut the contemporary English/lndonesia Dictionary yang disusun oleh Peter Salim (1991:1236) menyebutkan bahwa nationalisme adalah nasionalisme kebangsaan. Dalam kamus besar bahasa Indonesia (Depdikbud, 1997:684), definisi nasionalisme dinyatakan sebagai berikut: a. Paham (ajaran) untukmencintai bangsa dan negara sendiri b. Kesadaran keanggotaan dalam suatu bangsa yang secara potensial atau aktual bersama-sama untuk mencapai, mempertahankan, mengabdikan identitas, integritas, kemakmuran dan kekuatan bangsa itu, adalah semangat kebangsaan.

Dari pengertian tersebut dapat dipahami bahwa nasionalisme bermakna menyatakan suatu afinitas kelompok yang didasarkan 'atas bahasa, budaya/tradisi, keturunan/ tanah kerlahiran kadang-kadang pada agama, wilayah bersama dan komitmen 
bersama terhadap semua pengakuan lain atas loyalitas sebagai warganegaral seseorang. Dalam konteks bernegara yang dinuansai dengan doktrin politik, nasionalisme memberi basis dengan pembenaran secara ideologi bagi setiap bangsa untuk mengorganisasikan dirinya sendirike dalam entitas-entitas yang terbuka. Entitas-entitas itu pada umumnya mengambil bentuknegara nasional merdeka, sekalipun terdapat beberapa bentuk kultural yang melembaga pada setiap daerah bahkan dalam bentuk otonomi kedaerahan. Sebagaimana secara historis doktrin nasionalisme lahir dalam perjalanan sejarah negara Jerman pada abad ke-18 yang secara budaya bersatu, akan tetapi terpecah-pecah secara politik. Demikian halnya juga memiliki akar historis secara luas pada revolusi Prancis yang membidangi banyaknegara bangsa di Eropa (Riff, 1995:194). Nasionalisme merupakan ideologi dalam gerakan politik di negaranegara dunia ketiga berkembang sesudah negara-negara desimenasi diAsia, Afrika dan Amerika Latin yang membukakan diri dari kolonialis dan imperalis sesudah Perang Dunia Il. Pada zaman perang kemerdekaan di negara-negara terjajah itu, nasionalisme menjadi ideologi untuk perlawanan menghadapi penjajahan. Dalam perkembangannya, pasca perang kemerdekaan, nasionalisme tumbuh dalam pribadi diri sendiri seseorang selaku warganegara menjadi motor penggerak ideologi untuk membangun negara bangsa dalam melaksanakan pembangunan bangsa dengan prinsip berdiri pada potensi diri sendiri (secara berdikari).

Pada era globalisasi nasionalisme - dengan struktur bangunan bangsa negara menghadapi berbagai tantangan yang kompleks berupa timbulnya suatu tatanan dunia global yang melebihi garis-garis geografis tipologis, administratif, sosio kultural yang semakin menjadi suatu sistem kehidupan bangsa-bangsa sedunia.

\section{Faktor Pendukung Nasionalisme}

Untukmemberikan kejelasan mengenai nasionalisme/identitas nasional maka perlu dicermati dari faktor yang medukungnya. Sebagaimana ditegaskan oleh Suryo (2002), lahirnya identitas nasional suatu bangsa tidak dapat dilepaskan dari dukungan faktor obyektif, yaitu faktor-faktor yang berkaitan dengan geografis ekologis dan demografis serta faktor subyektif yaitu faktor-faktor historis, politik, social, dan kebudayaan yang dimiliki bangsa itu.Kondisi geografis ekologis yang memberikan bentuk Indonesia merupakan wilayah kepulauan dengan iklim tropis yang terletak pada persimpangan jalan komunikasi antar wilayah dunia di Asia Tenggara ikut mempengaruhi terhadap perkembangan kehidupan demografis, ekonomis, sosial, dan kultural bangsa Indonesia. Selanjutnya, faktor historis bagi Indonesia juga berpengaruh terhadap proses pembentukan masyarakat dan bangsa indonesia beserta identitasnya melalui interaksi berbagai faktor yang dimilikinya.Produk dari suatu interaksi faktorfaktor itu memunculkan proses pembentukan masyarakat, bangsa, dan negara, beserta identitas bangsa Indonesia yang menggema ketika dikumandang-kan nasionalisme menggelora pada sanubari Sumber Daya Manusia (SDM) termasuk Sumber Daya Manusia Wirausaha (SDMW) pada abad 20. Hal ini juga diharapkan setiap SDMW selaku warganegara tertumikan jiwa raga (sampai tetes darah penghabisan) untuk dipersem-bahkan seluruh aktivitas kehidupannya kepada ibu pertiwi bangsa dan negara tidak sebatas hitungan abad tetapi terus bersemangat sepanjang masa.Suryo (2002) menyatakan bahwa teori tentang munculnya identitas nasional sebagai hasil 
interaksi historis antara empat faktor penting yaitu: Faktor primer, faktor pendorong, faktor penarik, dan faktor reaktif. Untuk lebih jelas diuraikan sebagai berikut. a. Faktor pertama mencakup etnisitas, teritorial, bahasa, agama dan yang sejenis, b.Faktor kedua meliputi pembangunan komunikasi dan teknologi, lahirnya angkatan bersenjata modern serta sentralisasi monarki, c.Faktor ketiga mengenai bahasa secara gramatikal, pertumbuhan birokrasi dan pemantapan sistem pendidikan nasional, d.Faktor keempat berkenaan dengan penindasan, dominhasi dan pencarian identitas alternatif melalui memori rakyat.Keempat faktor tersebut pada dasarnya tercakup dalam proses pembentukan kebangsaan/ nasionalisme/ identitas nasional bangsa Indonesia yang sudah berkembang dari era sebelum mencapai kemerdekaan. Pada zaman kolonial, sebagai bangsa yang terjajah, semua kekuatan pemersatu rakyat Indonesia telah dikoptasi oleh kaum penjajah. Segenap potensi bangsa dipecahpecah demi menjaga status quo penjajah. Keberadaan semangat bangsa dengan munculnya Sumpah Pemuda, pada 28 Oktober tahun 1928 minimal dapat memberikan dukungan dalam upaya pencarian nasionalisme Indonesia (Karim, 1996:103) yang sekaligus penemuan jati diri' nasionalisme/identitas bangsa Indonesia. Sesuai kodrati sebagaj manusia yang dilahirkan memiliki perasaan bersama sebagai suatu bangsa senasib dan sepenanggungan, maka hal ini menjadi modal dan kekuatan utama bagi pembentukkan jiwa kebangsaan/nasional-isme/ identitas nasional. Persatuan yang bersifat nasional merupakan panggilan sebagai wargainegara untuk melakukan belanegara tidak hanya pikiran, tenaga dan materi melainkan juga sampaj titik darah penghabisan untuk kepentingan ibu pertiwi. Faktor penting lannya yang mendorong tumbuhnya kesadaran kebangsaan di Indonesia adalah digunakanya bahasa Melayu sebagai bahasa kebangsaan, yang bersama-sama agama Islam memecahkan kecenderungan nasionalisme sempit di Indonesia (Kahin, 1980:50). Bahasa melayu ternyata diterima masyarakat yang sebenarnya sudah memiliki bahasa daerah/suku yang cukup berpengaruh dan digunakan sebagai bahasa sehari-hari oleh masyarakat daerah/suku tersebut. Digunakannya bahasa Melayu dalam pergaulan antar etnis turut mempercepat tumbuhnya kesadaran kebangsaan di Indonesia Civic Education (2003:213). Pencairan identitas nasional bangsa Indonesia pada dasarnya inheren (melekat) erat dengan perjuangan masyarakat dan bangsa Indonesia untuk membangun konsep "Indonesia", sebagai atribut terbentuknya masyarakat dan bangsa baru atau Indonesia modern, dari keruntuhan bentuk masyarakat lama, baik yang bernuansa tradisional/kovensional maupun kolonial. Oleh karena itu, pembentukan identitas nasional melekat erat dengan persoalan-persoalan lainnya, yang berkaitan dengan dimensi sosial, kultural, ekonomi/kewirausahaan, maupun politik.

\section{Hak dan Tanggung Jawab Nasionalisme Masyarakat}

Seluruh anggota masyarakat harus menyadari bahwa nasionalisme untuk memberikan dukungan terhadap pemerintahan yang bersih berwibawa dan bertanggung jawab baik secara individual maupun kelompok. Karakter pribadi tampak pada tanggung jawab moral disiplin diri dan menaruh perhatian untuk penghargaan terhadap harkat dan martabat manusia dari setiap individu adalah wajib dimiliki oleh 
masyarakat. Demikian halnya dengan karakter publik yang tidak kalah penting. Kepedulian sebagai warganegara, kesopanan, kesantunan, mawas diri, rendah hati, mengindahkan rule of law, berpikir kritis, berkemauan untuk mendengar, melakukan negosiasi, musyawarah yang bertumpu pada semangat kepentingan bangsa agar terbudaya pada setiap warga negara berjiwa nasionlisme sesuai latar belakang masingmasing termasuk Sumber Daya Manusia Wirausaha (SDMW).Branson dkk(1999:2325) menyebutkan beberapa karakter publik dan pribadi sebagai berikut: a. Menjadi Anggota Masyarakat yang Independen. Karakter ini mencakup kesadaran pribadi untuk bertanggung jawab sesuai ketentuan, bukan karena keterpaksaan atau pengawasan dari luar; bertanggung jawab atas tindakan yang dilakukan dan memenuhi kewajiban moral dan hukum sebagai anggota masyarakat demokratis. b. Memenuhi tanggung jawab personal kewargaan di bidang ekonomi dan politik.Tanggung jawab ini mencakup memelihara/menjaga diri; memberi nafkah dan merawat keluarga; serta mengasuh dan mendidik anak .Di dalamnya termasuk pula mengikuti informasi mengenaj isu-isu publik, membayar pajak; menjadi wasit di pengadilan; melayani masyarakat dan melakukan tugas kepemimpinan sesuai bakat masing-masing.c. Menghormati harkat dan martabat kemanusiaan setiap individu. Menghormati orang lain berarti mendengarkan pendapat mereka; bersifat santun; menghargai hak-hak dan kepentingan-kepentingan sesama warga negara; serta mengikuti aturan "prinsip mayoritas" akan tetapi menghargai hak-hak minoritas untuk berbeda pendapat.d. Berpartisipasi dalam urusan-urusan kewarganegaraan secara efektif dan bijaksana.Karakter ini merupakan sadar informasi sebelum menentukan pilihan (voting) atau berpartisipasi dalam perdebatan publik yang tampak terlibat dalam diskusi yang santun dan kesungguhan serta memegang kendali dalam kepemimpinan bila diperlukan. Karakter tersebut juga meliputi melakukan evaluasi terhadap kepentingan pribadi seseorang sebagai warganegara harus dikesampingkan demi memenuhi kepentingan publik.e. Mengembangkan fungsi demokrasi konstitusional secara sehat.Karakter ini meliputi sadar informasi dan kepekaan terhadap urusanurusan publik untuk melakukan telaah terhadap nilai-nilaj dan prinsip konstitusional dengan memonitor yang menjadi keputusan para pemimpin politik dan lembaga-lembaga publik supaya cocok dengan nilai-nilai serta prinsip-prinsip tersebut. Karakter ini mengarahkan warga-negara supaya bekerja dengan kedamaian dan legal dalam bingkai perubahan perundang-undangan yang diasosiasikan tidak adil dan tidak bijaksana.

Untuk dapat mewujudkan berbagai pemikiran di atas, maka sangat diperlukan keberadaan dalam berbagai bentuk dukungan baik untuk perlindungan dari dan oleh anggota keluarga maupun masyarakat terhadap sesama. Maka dari itu, menjadi amat sangat penting dicermati untuk lebih mewujudkan nilai-nilai nasionalisme menuju pada pembelajaran demokrasi dalam proses kehidupan bernegara bagi umat manusia berbangsa.

\section{Karakteristik Sumber Daya Manusia Wirausaha}

Pembangunan bangsa di segala bidang akan berlangsung secara terus menerus sejalan perkembangan kemajuan zaman maka diperlukan warganegara yang juga memiliki jiwa inovasi, siap menghadapi tantangan/resiko dan proaktif/responsive. 
menerus sejalan perkembangan kemajuan zaman maka diperlukan warganegara yang juga memiliki jiwa inovasi, siap menghadapi tantangan/resiko dan proaktif/responsive. Karakteristik Sumber Daya Manusia Wirausaha adalah manusia yang mempunyai semangat juang dengan percaya diri, ketidaktergantungan, berorientasi pada tugas dan hasil, inisiatif energik tekad kerja keras, responsive dengan saran kritik, kreatif fleksibel inovatif, tidak putus asa/siap menghadapi resiko/ tantangan dan integritas dengan arah menuju lebih mementingkan keberhasilan karya usaha dalam pengabdian kepada bangsa. Jiwa tersebut merupakan manifestasi warganegara yang memiliki komitmen sebagai identitas bangsa. Setiap warga-negara dituntut untuk berlombalomba apa yang sudah diperbuat kepada bangsa. Jati diri/nasionalisme warganegara adalah penjelmaan potensi yang dapat melahirkan kekuatan demi kesentosaan negara dan bangsa. Patrick Kreiser, Louis Marino and K. Mark Weaver ( $2003: 2$ ) mengatakan bahwa entrepreneurship organizations have been conceptualized as possessing three main characteristic namely: innovation, risk talking and proactiveness. Untuk inovasi mencakup komitmen diri atau organisasi yang kuat untuk melakukan dukungan ide-de baru, hal baru, eksperimen dan kreativitas yang menghasilkan produk baru dalam layanan proses teknologi (Lumkin and Dess, 2001: 431). Menurut Miller (1988: 284) inovasi pada umumnya lebih lazim dan bermanfaat dalam lingkungan dinamik. Tanpa inovasi akan kehilangan pasar. Strategi proaktif dapat membiarkan berkesempatan dan mendapat keuntungan kompetitif dan menemukan lingkungan dinamik (Zahro, 1996). Jadi diharapkan bahwa perilaku Sumber Daya Manusia Wirausaha
(SDMW) adalah melakukan proaktif dan beradaptasi positif dengan tampilannya dalam lingkungan dinamik suatu bangsa.Untuk risk taking, Covin \& Slevin ( 1991) Organization yang tidak mengambil resiko dalam lingkungan dinamik akan kehilangan pasar dan tidak akan dapat membiayai suatu industri yang mandiri, kompetitif, dan agresif. Jadi, diharapkan bahwa organization risk taking akan beradaptasi positif dengan tampilan perusahaan dalam lingkungan dinamik bagi pertumbuhan ekonomi bangsa.

Sebagaimana dikemukakan oleh $\mathrm{M}$. Scarborough dan Thomas $W$ Zimmerer (1993:6-7) bahwa karakteristik SDMW dalam keterlibatan pembangunan bangsa adalah:a. Desire for responsibility, yaitu memiliki rasa tanggungjawab atas usahausaha yang dilakukannya. Seseorang yang memiliki rasa tangung jawab akan selalu mawas diri.b. Preference formoderate risk, yaitu lebih memilih resiko yang moderat artinya selalu menghindari resiko baik yang rendah maupun yang tinggic. Confidence in their ability to success, yaitu percaya akan kemampuan dirinya untuk berhasild. Desire for immediate feedback, yaitu selalu menghendaki umpan balik yang segera. High level of energy, yaitu memiliki semangat dan kerja keras untuk mewujudkan keinginannya demi masa depan yang lebih baik f. Future orientation, yaitu berorientasi kemasa depan, perspektif dan berwawasan jauh kedepan.g. Skill at organizing, yaitu memiliki ketrampilan dalam mengorganisasikan sumber daya untuk menciptakan nilai tambah. h. Value of achievement over money, yaitu lebih menghargai prestasi dari pada uang.

Dari berbagai pendekatan pandangan tersebut setiap warganegara akan memberikan andil yang tidak kecil dalam pembangunan bangsa. Untuk itu tidak 
jati diri bangsa/nasionalisme terekspresj pada semua bidang pembangunan bangsa sepanjang masa. Jadi sebagai warganegara Indonesia bukan warganegara yang cengeng/lemah dari sisi KSDM akan tetapi perlu digali kesadaran potensi yang telah dimiliki oleh manusia selaku warganegara untuk menghadapi panggilan tugas suci dalam kehidupan berbangsa.

\section{Pemahaman Sumber Daya Manusia Wirausaha}

Dalam rangka -melakukan aktivitas, SDMW bertumpu pada life skill (kecakapan hidup). Slamet PH (2001:8), dalam pendidikan kecakapan hidup, mencakup basic skill dan instrumen skill. Untuk memperjelas pengertian ini dilakukan pembahasan mencakup: life social skill (Knowledge, skill and atitude) serta dimensi religion dan sosial dalam karya wirausaha untuk pembangunan bangsa.

Kecakapan hidup merupakan keterampilan hidup yang harus dimiliki oleh setiap warganegara dan diperlukan oleh seseorang untuk menjalankan kehidupan berbangsa dan bemegara. Dalam kehidupan berbangsa bagi pembangunan bangsanya sumber daya manusia bangsa perlu memiliki orientasi kehidupan karya Usaha nyata ke masa depan. Sebab karya usaha nyata bukan dilakukan untuk sementara tetapi sepanjang kehidupannya berkreasi dalam pembangunan bangsanya. Oleh karena itu, seorang yang berjiwa SDMW akan melakukan apapun untuk keberhasilan sebagai kiprah nyata, bukan tanda tetapi bakti nyata jiwa raga meraih dan menjaga nama prestasi bangsa, yang merupakan kepribadian jati diri anak bangsa sebagai identitas bangsa/nasionalisme yang diapresiasikan dalam berpartisipasi untuk pembangunan bangsa. Dengan demikian, kepribadian, pengetahuan, keterampilan dan mental SDMW sebagai warganegarayang memiliki basis wirausaha sangat mendukung terhadap perwujudan jiwa nasionalisme bahkan sebagai pemimpin. Dalam era globalisasi sekarang pimpinan semua unsur negara bangsa yang diperlukan bermotifkan SDMW.Berkenaan dengan life social skill tersebut, Thomas N. Garavan and Barra O' Cinneide (1995:4) menjelaskan tiga ciri utama inovator dan wirausaha yaitu: knowledge, skill and attitudes. Knowledge, mendasari tindakan yang dilakukan dalam kegiatan sehingga menjadi kebiasaan cara menganalisa perkembangan kegiatan berbangsa. Skill ( pendapat kedua ini ) menggambarkan perhatian yang lebih kuat pada apresiasi praktik riil dengan ketrampilan sesuai keahliannya dalam. pembangunan bangsa dan attitude adalah penekanan penyampaian secara keseluruhan dengan sikap perilaku membangun bangsa.Jadi untuk melakukan kegiatan berbangsa dengan sebutan identitas bangsa/nasionalisme tidak hanya asal mengakui tempat kelahiran sebagai warganegara tetapi harus melakukan tindakan yang berkepribadian dengan bentukan diri dari baik life skill itu, maupun life social skill sebagai insan warganegara berkarakteristik SDMW yang nasionalisme sejati.

\section{Implikasi Ajaran Islam Terhadap Pemahaman SDMW- Nasionalisme}

Kecakapan hidup dengan ketiga ciri utama yang diuraikan di atas itu masih diperlukan kekuatan dari dimensi ajaran agama. Islam yang dibawa oleh Rasulullah SAW dalam melakukan dakwah mencerminkan kerja keras, sehingga dapat berhasil mencapai kejayaan. Buchari Alma (2000:197) bekerja keras bukan hanya dilakukan pada saat memulai saja, akan tetapi terus dilakukan walaupun sudah 
berhasil. Lakukan perbaikan terus-menerus atas apa yang telah dikerjakan dan jangan terlena karena suatu keberhasilan.Kemauan keras (azam) dapat menggerakkan motivasi untuk bekerja dengan sungguh-sungguh. Orang atau bangsa yang berhasil adalah yang mau bekerja keras, tahan menderita, dan berjuang memperbaiki nasibnya. Sebagaimana dinyatakan dalam Al-Qur'an surat Ali Imron, 159 yang artinya jika engkau salah berazam maka bertaqwalah kepada Allah. Perintah Allah SWT tentang upaya secara konkrit diantaranya:-Kewajiban seorang memberi makan dan pakaian kepada mereka dengan cara ma'ruf (Q.S. Al Baqoroh: 233 ). -Carilah kebahagiaan yang telah disediakan Allah di akhirat kelak, dan jangan kalian melupakan kebahagiaan kalian di dunia ini (Q. S. Al Qashos:77).

Sesungguhnya Allah telah mewajibkan kalian berusaha, maka oleh sebab itu hendaklah kalian berusaha (H. R. Thabrani ). - Apabila kalian selesai sholat subuh, jangan kalian tidur dan malas mencari rizki ( H.R. Thabrani ).- Ya Allah, berikanlah keberkahan kepada umatku pada usaha yang dilakukannya di pagi hari ( $H$. $R$. Tirmidzi ).Jika dicermati dari ajaran islam tersebut dapat terbumikan dalam sanubari setiap warganegara Indonesia maka peluang membangun bangsa menjadi bangsa kamil dengan motor SDMW akan sangat memberikan dukungan tercapainya tujuan pembanguna manusia seutuhnya. Implikasi pemahaman terhadap SDMW nasionalisme tidak semu dalam menuju keberhasilan pembangunan materiil dan spiritual. Dengan demikian, akan diperoleh keseimbangan kesehatan jasmani dan rohani bagi suksesnya dalam jiwa manusia selaku warganegara bukan di bibir tetapi ketetapan hati yang difragmenkan dalam tindakan dengan bekal keterpaduan pengetahuan, ketrampilan dan perilaku luhur tekad tinggi dan memberikan kontrol sehingga diperoleh amal perbuatan saleh sebagai penguat dorongan terbentuknya kepribadian SDMW nasionalisme.

\section{Strategi Pemahaman SDMW Nasionalisme}

Setiap melakukan kegiatan perlu mempertimbangkan hal-hal berkenaan dengan maksudnya. Dasar pertimbangan suatu strategi dipilih diantaranya: (1) memperhatikan tujuan yang menjadi target; (2) materi yang kompleks dalam pembangunan; (3) problematika mediasi bidang garapan dalam pembangunan; (4) berbagai teknik sesuai dengan metodenya dan (5) kharakteristik masyarakat.Untuk pemahaman SDMW nasinalisme diperlukan strategi yang cocok agar materi pemberdayaan yang dijalankan oleh pemimpin negara bangsa bukan teori omong kosong akan tetapi riil dilakukan dalam kehidupan nyata masyarakat. Dengan demikian, masyarakat merasakan akan gerakan pemberdayaan sehingga terasa disapa guna, berdaya guna dan berhasil guna untuk peningkatan pertumbuhan segala bidang pembangunan bangsa yang berorientasi kepada pendapatan asli daerah bagi kepentingan rakyat.

Pada era globalisasi ini kemajuan di bidang teknologi, komunikasi dan informasi mendorong perubahan sosial, interaksi sosial tidak lagi monologi melainkan dinamologi. Perubahan sosial menimbuikan konsekuensi logis seperti: meningkatnya tuntutan keterbukaan, desentralisasi, demokratis dan bergeraknya begitu cepat dari perkotaan sampai dengan masyarakat.Masyarakat cenderung bergeser dari agraris yang selaras dengan alam ke industri. Korelasi masyarakat agraris dengan industri terus berkembang. 
Perken wangan menuntut pelaku manejemen pemimpin yang peka dan responsibility tinggi terhadap kompleksitas kehidupan masyarakat. Maka, setiap warganegara apapun latar belakangnya periu memiliki efeksinergistik dalam menangkap gejala problematika yang sangat kompleks sehingga terlatih dan terpatri SDMW nasionalisme.Strategi pemahaman pemberdayaan masyarakat bangsa dengan karakteristik SDMW dilakukan untuk mengisi strategi pembangunan bangsa dalam meningkat kualitas segala bidang demi kepentingan masyarakat berbangsa. Pemberdayaan orang, kelompok atau masyarakat dapat dilakukan dengan berbagai cara yang bermakna. Sebagai upaya terhadap masyarakat menuju berdaya mutu sehingga mampu mengurus kepentingan sendiri secara mandiri. Dengan demikian, Sadu Wasistiono (2003:60) inti pemberdayaan adalah menciptakan kemandirian baik dari individu, kelompok maupun masyarakat dan bangsa.Proses pemberdayaan masyarakat ditentukan oleh dua faktor yaitu eksogen dan endogen. Eksogen adalah faktor-faktor berasal dari luar masyarakat baik berkenaan kebijakan pemerintah, bantuan biaya, bantuan tenaga penyuluh dan lain sebagainya.

Endogen, faktor dari dalam yang berkaitan dengan tata nilai, adat kebiasaan, sikap mental dari masyarakat itu sendiri. Untuk upaya pemberdayaan masyarakat maka faktor endogen merupakan determinan bagi suksesnya proses itu. Lebih tegas Sadu Wasistiono (2003:61) mengemukakan bahwa pemberdayaan masyarakat melalui transformasi semangat kewirausahaan pada dasarnya adalah upaya mengubah sikap mental, sebab titik lemah bangsa Indonesia justru terletak pada sikap mentalnya. Sadu Wasistiono selanjutnya juga menjelaskan tentang transformasi semangat kewirausahaan dimaksudkan sebagai pemasukan virus mental ke dalam setiap anggota masyarakat melalui berbagai cara antara lain (a) melalui penyuluhan; (b) pemberian contoh nyata; (c) pemberian kesempatan dan melalui proses pembelajaran secara terus menerus melalui program pendampingan.Apabila cara itu dapat dilakukan oleh kepemimpinan pemerintahan maka berbagai peluang yang timbul merupakan kekuatan yang dimiliki masyarakat dapat berdaya guna optimal dalam pembangunan. Dengan demikian, akan terlihat sudut pandang masyarakat (sebagai pendekatan etnosentris) dalam proses pemberdayaan masyarakat bukan dari sudut pemimpin pemerintahan.Oleh karena itu, pemimpin pemerintahan perlu memiliki sifal kepemimpinan pemerintahan wirausaha yang bermental character building yakni membangun masyarakat bangsa berkarakter dengan semangat kejiwaan. Ordway Tead dalam (Kartini Kartono, 1983: 37) menyebutkan sepuluh (10) sifat SDMW berkepemimpinan wirausaha yaitu: (1) energi jasmaniah dan mental, seorang pemimpin memiliki daya tahan keuletan, kekuatan yang luar biasa seperti tidak akan pernah habis. Demikian pula semangat, juga motivasi kerja, disiplin, kesabaran, daya tahan batin, kemauan yang luar biasa untuk mengatasi semua permasalahan yang dihadapi; (2) Kesadaran akan tujuan dan arah, memiliki keyakinan teguh akan kebenaran dan kegunaan dalam mencapai tujuan yang terarah; (3) Antusiasme, yakin tujuan yang hendak dicapaj akan memberikan harapan sukses dan membangkitkan semangat optimisme dalam bekerja; (4) Keramahan dan Kecintaaan, sifat ramah memiliki kebaikan dalam mempengaruhi orang lain sehingga menimbulkan kasih sayang, simpati yang tulus, diikuti dengan kesediaan berkorban 
untuk mencapai kesuksesan; (5) Integritas, memiliki perasaan sejiwa dan senasib sepenanggungan dalam menjalankan kepemimpinannya; (6) Penguasaan Teknis, menguasai suatu pengetahuan dan keterampilan teknis; (7) Ketegasan dalam Mengambil Keputusan, memiliki kecerdasan dalam mengambil keputusan sehingga mampu meyakinkan bawahan dan mendukung kebijakan yang telah diambil dalam pelaksanaannya; (8) Kecerdasan, kemampuan melihat dan memahami sebab akibat dari suatu gejala dan cepat menemukan solusi untuk mengatasi kesulitan dengan cara yang efektif; (9) Keterampilan Membelajarkan, perlu memiliki kemampuan mendidik, mengarahkan memotivasi untuk berbuat sesuatu yang menguntungkan denan mengevaluasi pekerjaannya dan (10) Kepercayaan, menimbulkan kesenangan bawahan maka akan muncul kepercayaaan dari bawah terhadap pemimpin.Sadu Wasistiono (2003:62) mengemukakan yang dimaksudkan dengan semangat wirausaha adalah suatu etos (semangat kejiwaan) dengan ciriciri:

1. Berorientasi ke masa depan bukan hanya ke masa lalu

2. Berani mengambil resiko denga penuh perhitungan

3. Berani bertanggung jawab terhadap keputusan yang telah diambil, tanpa berupaya melimpahkan kesalahan pada pihak lain

4. Memegang teguh janji

5. Penuh daya kreativitas dan inovasi

6. Cenderung berpikir positif

7. Sangat menghargai waktu

\section{Pandangan Kedepan Pemahaman SDMW Nasionalisme}

Perspektif pemahaman SDMW nasionalisme terhadap pertumbuhan dan perkembangan ekonomi berpengaruh kepada pembangunan ekonomi suatu masyarakat dalam pembangunan bangsa. Ahli ekonomi terkemuka Schumpeter telah mengembangkan model wirausaha yang merangkum semua kegiatan usaha yang membawa kepada satu bentuk pembaharuan. Model yang dikembangkan adalah inovasi sebagai antisipasi terhadap kegiatan keusahawanan yang dilaksanakan individu dikenali sebagai usahawan dalam pembanguna sektor ekonomi bangsa. Secara psikologis perspektif, para ahli akademik menyebutkan tiga teori dan model utama yaitu model baku, teori keperluan terhadap tujuan, dan model psikodinamik. Model baku menjelaskan bahwa SDMW/ usahawan perlu memiliki jati diri atau "locus of control, secara mendalam. Sifat-sifat yang perlu dimiliki adalah inisiatif, upaya merancang, mengambil resiko peluang. Teori keperluan kepada pencapaian yang menerangkan bahwa individu mempunyai kehendak pencapaian tinggi adalah golongan yang jika mengambil tanggung jawab ke arah mencapai sesuatu matlamat dengan usaha sendiri. Model psikodinamik dijelaskan oleh De Vries dalam Dollinger (1995) dikutip oleh AB.Azis yusuf (2003:11) bahwa usahawan merupakan individu yang sama kecilnya dan tidak berpeluang untuk mendapat kemudahan-kemudahan tertentu.Hal tersebut menyebabkan untuk satu satu alternatif bila keadaan tidak menguntungkan lagi. Pandangan perspektif pemahaman 'SDMW nasionalisme perlu digerakkan secara serentak menjadi program kebangsaan sehingga melahirkan kekuatan negara bangsa yang memiliki kebakuan atas keperluan/kebutuhan berorientasi pada target nyata untuk pembangunan bangsa seutuhnya. 


\section{Penutup}

Dari uraian tersebut dapat dikemukakan bahwa : (1) Pada umumnya masyarakat menghadapi percepatan perubahan sosial dan perkembangan zaman tersebut memicu untuk melakukan inovasi sebagai pendorong perubahan sosial dalam pembangunan bangsa. Masyarakat yang terjelma adalah Sumber Daya Manusia Wirausaha (SDMW) yang memiliki kepribadian menjadi warganegara yang siap memahami bela negara/identitas bangsa/nasionalisme dalam pembangunan bangsa.(2) Transformasi semangat SDMW yang dimiliki oleh setiap warganegara membentuk character building yang merupakan suatu etos bercirikan: (a) Berorientasi ke masa depan bukan hanya ke masa lalu; (b) Berani mengambil resiko dengan penuh perhitungan; (c) Berani bertanggung jawab terhadap keputusan yang telah diambil, tanpa berupaya melimpahkan kesalahan kepada pihak lain; (d) Memegang teguh janji; (e) Penuh daya kreativitas dan inovasi; $(f)$ Cenderung berpikir positif dan (g) Sangat menghargai waktu (h) Semangat bekerja yang tidak mengenal waktu ulet, tangguh, percaya diri, jujur, silahturohmi, networking, rasional dan mampu menangkap peluang ke depan.

\section{Daftar Pustaka}

Buchari Alma.2000. Kewirausahaan. Bandung : CV.Alfabeta.

Branson, Margaret S. dkk. 1999 Belajar Civic Education dari Amerika. Yogyakarta: LkiS dan The Asia Foundation.

Civic Education.2003. Pendidikan Kewarganegaraan.Yogyakarta: Diktilitbang PP Muhammadiyah.
Covin, J.G and Slevin D.P. 1991. A conceptual Model of. Entrepreneurship as Firm Behavior. Entrepreneurship Theory and Practice. Volume 16 (1),p7-25.

Entrepreneurship Education and Training Programmes: A Review and Evaluation-Part 1. Journal of European industrial Training. Volume p.1-15.

Kahin,George McTurnan.1980. Nasionalisme dan Revolusi di Indonesia.Kuala Lumpur: Dewan Bahasa dan Pustaka Kementrian Pelajaran Malaysia.

Karim, M.R. 1996. Arti dan Keberadaan Nasionalisme.Analisis CSIS XXV (2):95-108

K. Mark Weaver. 2003. Assessing The Relationship Between Entrepreneurial Orintation, The Extemal Environmen, and Firm Permomance. Joumal Frontiers For Entrepreneurship Research. By Babson College.Volume. p. 1-10.

Lumkin, G.T., and Dess, G.G. 2001. Linking two dimensions of entrepreneurial orientation to firm perfomance: The moderating role of environment and industry life cycle.

Journal of Business Venturing. Volume 16, p. 429-451.s

Miller, D. 1988. Relating Porter's business strategies to environment and structure: Analysis and perfomance implications. Academy of Management Joumal,

Muhamad.2000. Lembaga-lembaga Keuangan Umat Kontemporer. Yogyakarta:UII Pres. 
Riif, MichaelA. 1995. Kamus Ideologi Politik Modern.Yogyakarta: Pustaka Pelajar.

Sadu Wasistiono.2003. Kapita Selekta Menejemen Pemerintahan Daerah. Fokus Media. Bandung. Reference

Salim, Peter.1991.The Contemporary English indonesia Dictionary. Jakarta: Modern English Pres.

Scarborough,Norman M.,Thomas W Zimmerer.1993. Efective Snall Busines Management. NewYork: MacMillan Publishing Company.

Surjo,Joko.2002.Pembentukan Identitas Nasional. Makalah pada seminar
Terbatas pengembangan Wawasan tentang Civic Education. Yogyakarta: LP3 UMY.

Suryana.2003.Kewirausahaan.Jakarta:Salemba Empat.

Thomas N. Garavan and Barra O'Cinneide. 1995.

Zahra, S.A. 1996. Technology strategy and financial perfomance: Examining the moderating role of the firm's competitive environment. Joumal of Business Venturing, Volume11(3), p. 189-219. 